\title{
COUNTERING RADICALISM THOUGHT ON ISLAM A Study of Ibrahim M Abu Rabi's Thought
}

\author{
Muh. Mustamsikin \\ Wahid Hasyim University Semarang \\ Mustamsikin@gmail.com
}

Ghufron Hamzah

Ph.D Student of School of Graduate Studies, Sunan Kalijaga State Islamic

University (UIN) Yogyakarta

ghufronhamzah@gmail.com

The terrorist event and the destruction of the sea alms tradition in Bantul recently were quite surprising, because as we know that Yogyakarta is rich in cultural traditions. The phenomenon of violence with greater religious motives also occurred in Indonesia, such as the Bali Bombing on October 12, 2002, and more violent was the September 11, 2001 event at the WTC United States. The question is why does an understanding arise that justifies acts of terrorism in the name of religion? What is the solution offered by Ibrahim M Abu Rabi 'in responding to the phenomenon of terrorism in the name of religion? This paper will explain the thoughts of Ibrahim M Abu Rabi 'about the importance of reexamining the nature of Islamic thought when there are many Western accusations that the teachings of Islam legalize acts of violence and terrorism. Abu Rabi took three approaches in starting his study; (1) starting with the historical development of Islamic modernization, (2) education in the Islamic world, and (3) contemporary elites and the rise of religion in the Arab world. The philosophical, critical theological, sociohistorical, and anthropological approaches to the study of Islam that were implied by Abu Rabi to bring Islam to the advanced conditions become accumulated in interconnected integrative ways of thinking.

Keywords: Ibrahim M Abu Rabi ', Radicalism, Terorism, and Integrative Interconnection.

\section{A. Introduction}

Events of terror and the destruction of "Sedekah Laut" event in Bantul in 2018 were quite surprising, because as we know that Yogyakarta is rich in cultural traditions. ${ }^{1}$ The phenomenon of violence with a larger religious motive has also occurred in Indonesia, such as the Bali Bombing incident on October 12, 2002 and what was even more violent was the September 11, 2001 incident at the WTC, United States.

Since the terrorist attacks on the WTC in the United States on September 11, 2001, there have been symptoms of Islamophobia ${ }^{2}$ where many Westerners claim

\footnotetext{
${ }^{1}$ https://www.liputan6.com/regional/read/3667306/saat-sedekah-laut -destroyed-by-masked-
} masses in Bantul.

2 Islamophobia can be defined as behavior or attitudes or actions that show hatred, fear, and dislike that are relatively active without an objective basis for Islam. See: Adang Kuswaya, Against Islamophobia (Sukoharjo: Kekata Group, 2020), p. 3-4. 
Islam as a religion of violence. Violence is considered by a number of Western circles as a phenomenon inherent in Islamic teachings itself and rooted in its religious texts. Western circles also question the relationship between violence and sacredness in Islam.

Comments accusing Islam of being terrorist actors has become the subject of a growing discussion which then connects it with jihad which is textually contained in the sources of Islamic law, both the Koran and the Hadith. However, these accusations make the definition of jihad distorted and manipulative. The Bali bombing, the Kuningan bomb and others that occurred in Indonesia further strengthened the western media to portray Islam as synonymous with terrorism.

The influence of traditional education on the emergence of radicalism (although in this case the author does not fully agree with the term traditional education when it is not specifically mentioned, namely textual extremism) can be seen from the phenomenon of several acts of terror in Indonesia, where some suspected terrorists are managers or students of a educational institutions. Sidney Jones, Director of the International Crisis Group (ICG) called it "Ngruki Network" in an article entitled "Al Qaeda in Sotheast Asia : the case of the Ngruki network in Indonesia ". Sidney Jones said that most people who commit acts of terror in this country have their estuary to the Al Mukmin Ngruki Islamic Boarding School, then Sidney calls it "Ngruki Network". ${ }^{3}$ As we know, those convicted of terrorism cases, Abu Bakar Ba'asyir, Ali Mukhlas, Amrozi, Imam Samudra, and Ali Imron are founders and students of the Ngruki Islamic Boarding School.

Ibrahim was challenged to elaborate on this issue to the theological roots that triggered violence (theology of violence). Ibrahim M. Abu Rabi 'in his article entitled A Post September 11 Critical Assessment of Modern Islamic History, describes three phases of the approach to describe this problem, first, the history of the development of Islamic modernization. Second, education in the Islamic world. Three, contemporary elite and religious revival in the Arab world. The reconceptualization of texts, cultural traditions, and intellectual realms as an effort to solve this problem is a renewal step in the field of epistemology which is intended as a progressive step to deal with problems more comprehensively.

\section{B. Biography of Ibrahim M. Abu Rabi '}

Nickname as an intellectual son of two continents deserves to be attached to Ibrahim Abu Rabi'. Even though he was born in Nazareth, Galilee, Palestine in 1956, Abu Rabi 'apparently holds dual citizenship: Israel and the United States. His

3 See, ES. Supriyadi, Ngruki and the Terrorism Network, Tracing the Traces of Abu Bakar Ba'asyir and his Jarigan from Ngruki to the Bali Bombings, (Jakarta: Al Mawardi Prima, 2003), p. 31 
scholarly odyssey began at Bir Zit University in the West Bank. He continued his studies and obtained his master's degrees at Chincinati University and Temple University. The doctorate (Ph.D) he got at Temple University Depattement Of Religion in $1987 .{ }^{4}$

Ibrahim M. Abu-Rabi is Professor and Chair of the Edmonton Muslim Community Council in Islamic Studies in the Department of History and Classics at the University of Alberta, Edmonton, Canada. His main areas of academic specialization is Middle East and International Relations. He holds a $\mathrm{Ph} . \mathrm{D}$. in Islamic Studies, with a concentration in Modern Islamic Thought and Comparative Islamic Culture, from the Department of Religion of Temple University in 1987. His dissertation was entitled, "Islam and Search for Social Order in Modern Egypt: An Intellectual Biography of Shaykh al-Azhar 'Abd Halim Mahmud."(Islam and the Search for Social Order in Modern Egypt: Intellectual Biography of Shaykh alAzhar 'Abd al-Halim Mahmud). Prior to that, he received an MA in Religious Studies from Temple University (1983) and an MA in Political Science from the University of Cincinnati (1982). Prof. Abu-Rabi was born and attended primary and secondary schools in Nazareth, Galilee, Palestine. He is fluent in English, Arabic, Hebrew, French, German and Turkish.

Seeing his intellectual wandering, experiences and scientific insights, it is not surprising that his competence has resulted in various works related to the problems of contemporary Islamic thought, religious studies and Islamic studies. Apart from his dissertation entitled "Islam and Search for Social Order in Modern Egypt: An Intellectual Biography of Shaykh al-Azhar 'Abd Halim Mahmud”, Abu Rabi' is considered a very productive writer with contributive works. Among the works he has written are: (1) Book: Work in Progress Neolibralism and Its Discontent: Studies in Post-1967 Arabic Thought; Intellectual Origins of Islamic Research in The Modern Arab World (New York: State University Of New York Press, 1996); Islamic Resurgence and The Challenge of The Contemporary World: A Round Table Discussion with Professor Khurshid Ahmad (Tampa: The World and Islam Institute, 1995); The Pearls of Wisdom by the North African Mystic Ibn alSabbagh (Albany: State University of New York Press); The Blackwell Companion to Contemporary Islamic Thought (Oxford: Blackwell Publishing, 2006); Contemporary Arab Thought: Studies In Post-1967 Arab Intellectual History (London: Pluto Press, 2004). (2) Article: A Post September 11 Critical Assessment of Modern Islamic History(2002); Between Sacred Text and Cultural Constructions: Modern Islam as Intellectual History (2000); Arabism, Islamism, and The Future of 
The Arab World: A Review Essay (2000); Globalization: A Contemporary Islamic Response? (1998); An Islamic Response to Modernity (1998). ${ }^{5}$

\section{Historical Developments in the Modern World}

Modernization and capitalism in the 17th and 18th centuries had a major impact on the economic and political order in the world. The progress of Western progress then prompted them to undertake the project of colonialism and imperialism to parts of third countries in search of natural resources. This European progress also reflects the decline that occurred in the Muslim world in the 19th century where stagnation of thought and economic decline were inevitable. This social reality invites responses from Muslim intellectuals who are reflected in their works, speeches and political struggles.

The response of the Muslim world to the challenges of colonialism took a variety of forms, all of which aimed to revive and reconstruct religious, social, political and economic institutions. These responses can be classified into three categories: modernization, nationalism, and Islamic revivalism. ${ }^{6}$

\section{Modernization}

Modernization carried out by Muslims was marked by the struggle of the Ottoman dynasty to carry out various reforms in the kingdom. The pioneers of modernization in Turkey are political elites, bureaucrats, intellectuals and scholars. The involvement of ulama in modernization is inseparable from their efforts to protect the people. However, this modernization is not completely successful because prevented the collapse of the political authority of the Ottoman dynasty at the end of World War I (1914-1918). ${ }^{7}$

The modernization program known as tanzimat ${ }^{8}$ was promoted by the central government in facing European threats. tanzimat Thiswas adopted to serve as a topdown modernization policy. To save Turkey, the only way is to fully understand the discourse of nationalism, secularism and modernization.

\section{Nationalism}

\footnotetext{
${ }^{5}$ Hasan Mahfudh, From Ibrahim M. Abu Rabi 'on the Problems of Contemporary, Islamic StudiesMillati, Journal of Islamic Studies and Humanities Vol. 1, No.1, June 2016, p. 23-39.

${ }^{6}$ Ibrahim M. Abu Rabi ', "A Post September 11 Critical Assessment of Modern Islamic History" in Ian Markham and Ibrahim M. Abu Rabi', (Oxford: Oneworld Publications, 2002), p. 22-45.

7 Ibid, p. 24.

8 Tanzimat is a reformation movement in Turkey which was originally a modernization in the body of the Ottoman Turks, the most important thing is modernization in the military and the tendency of the bureaucratic elite to imitate the lifestyle of the upper class in the West due to the interest in Western civil society. This program was carried out by Mustafa Rasyid Pasya and Mehmed Sadik Risyad Pasya which was then followed by the birth of thecharter Humayun, which contained the position of Europeans, Young Usmani, and Young Turks. This movement then gave birth to reforms carried out under the leadership of Mustafa Kemal Attaturk. Read: John L. Esposito (ed), The Oxford Encyclopedia of The Modern Islamic Word, vol. 4 (New York: Oxford University Press, 19995), p. 183-185.
} 
Nationalism is an idea and spirit that was ignited in the second phase of the 19th century as a response to the difficulties of the Muslim world in facing the challenges and development of the European nation. Referring to Anderson's opinion, Nationalism is defined by Abu Rabi 'as a view of a limited state, unlike the view of generality as emerged in the Christian (traditions Christendom) and Islamic (Ummah). Abu Rabi 'emphasized that it was these nationalist movements that led his people to fight against colonialism even though in fact they did not use religious jargons in their speeches or national orations. Examples of this nationalist movement are those led by figures such as: Soekarno in Indonesia, Kemal Attaturk in Turkey, Mohammad Ali Jinnah in Pakistan and Gamal Abd al Naser in Egypt. ${ }^{9}$

To fight imperialism, nationalism is directed at two things, spiritual and institutional. Spiritually, nationalism seeks to secure the state's sovereignty, the past and cultural identity. Where as institutionally, nationalism tries to build the country by studying Western science and building Western institutions. These two functions of nationalism were adopted by Abu Rabi 'from Partha Chatterjee. ${ }^{10}$

\section{Islamic revivalism}

Islamic revivalism is another form of response to the challenges of colonialism. According to Esposito, ihya ' (revive) and tajdid (renewal) are two key words in Islamic revivalism. ${ }^{11}$ According to groups with this view, Islam is not a problem, meaning that the decline and stagnation of the Islamic world is not caused by Islam, on the contrary Islam is the solution. The stagnation that occurs in the Muslim world is due more to the fact that Muslims do not want to stick to Islamic teachings. Therefore, returning to Islam is a call as well as the only way to restore the glory of Islam. Revivalism in the Islamic world can be divided into four periods: 1) pre-colonial; 2) colonial; 3) post-colonial; 4) post-nation-state. Wahabiyah is a representation of the pre-colonial revivalism movement. Wahabiyah emerged from a reaction to the internal decandency of Muslims who were considered to have deviated from authentic teachings. Meanwhile Muhammadiyah and Nahdhatul Ulama were revival organizations in the colonial era. Colonial revivalism can also be represented by the Muslim Brotherhood in Egypt and Jemaah Islamiyah in India. These colonial era revivalist organizations were engaged in advancing the field of education and had the ambition to control the power to fight the invaders. Postcolonial revivalism was represented by the emergence of the jihadist movement in

9 Ibrahim M. Abu Rabi ', “A Post September 11 Critical Assessment of Modern Islamic History",... p. 24.

10 Ibid.

11 See, As'ad Abu Khalil, "Revival and Renewal" in The Oxford Encyclopedia of the Modern Islamic World, vol. 3, ed. John L. Esposito et al. (New York: Oxford University Press, 1995), 431 
Egypt in 1970-1980. Meanwhile, post-nation-state revivalism is represented by the Taliban and Al-Qaeda movements. ${ }^{12}$

For Abu Rabi 'the awakening of Islam at the hands of these movements becomes problematic when they are unable to position and distinguishes the realm of the awakening. Is the Islamic revival doctrinal, philosophical or historicalpolitical in nature ${ }^{13}$ The central theme of the idea of renewing thought in Islam lies in the key word i'adatul Islam, namely the desire of the Muslim community to restore the role of the Islamic world in the global arena of world civilization.

\section{Education in the Muslim World: Between Modern and Traditional?}

Ibrahim saw that many Muslim countries have accepted modernization after the independence era. Indonesia, Pakistan and Egypt have encouraged modernization in the field of education and their institutions by creating open education for all their citizens. However, in other Muslim countries there are still a number of policies that reject the modernization of education with the hidden aim of maintaining the status quo. Seeing this reality, Muslim countries need a pluralistic and inclusive educational environment, where educational institutions accept curriculum reforms. ${ }^{14}$

Islamic education institutions are in dire need of modernization. Ibrahim agreed with Abd al-Majid al-Charfi, a Tunisian thinker, who proposed the modernization of Islam by offering a distinctive understanding between "Islamic" and "Islamic thought" (al-fikr al-Islami). Islam is a sacred religion, while Islamic thoughtIslamic thought isthat is not sacred such as tafsir, hadith, kalam, fiqh, Sufism, and others. Islam is a product of God, while Islamic thought is a product of humans. Islam is single, but Islamic thought is certainly diverse. However, traditional Muslims often of their understanding of Islam as Islam itself, resulting in a cult of understanding Islam (Arkoun calls it act on behalfat taqdis al afkar ad diniyah). This distinction between Islam and Islamic thought is important in the modernization process in Islamic educational institutions, because with differentiation of the two things will allow the emergence of dynamic innovation and renewal.

The medieval educational curriculum in the countries of Saudi Arabia, Pakistan, Afghanistan and Yemen is still traditional. Traditional education still has not received critical analysis based on social sciences and critical philosophy.

12 Ibrahim M. Abu Rabi ', “A Post September 11 Critical Assessment of Modern Islamic History",... p. 25-26.

${ }^{13}$ Ibrahim M. Abu Rabi ', Intellectual Origins of Islamic Research in The Modern Arab World (New York: State University Of New York Press, 1996), p. . 10.

14 Ibrahim M. Abu Rabi ', “A Post September 11, Critical Assessment of Modern Islamic History", ... p. 28-29. 
Traditional education is too fixated on the system of memorizing and repeating classical thought products without any innovation. Abu Rabi agrees with the statement of Rifaat Said, an Egyptian thinker, that traditional education is very literalistic. Ideologically, traditional studies are more constructed to defend the status quo. Modern and contemporary reading of turats ${ }^{15}$ is needed in order for a paradigmatic transformation from traditionalism to modernism, as was carried out by Muhammed Abed al Jabiri in his Naqd al-Aql al-Arabi project. ${ }^{16}$

\section{E. Crisis Perspectives and Methodology in Islamic Studies}

When examining the problems of Islamic studies, Abu Rabi 'again emphasized the importance of the distinction between Islam and Islamic thought or Islamic studies itself. Referring to Ibn Khaldun's opinion, Abu Rabi 'believes that Islamic studies are different from Islam. If Islam refers to eternal revelation and sacred religion, then Islamic thought or study refers to all development of Muslim science such as the interpretation of the Koran, hadith, fiqh, kalam, Sufi and so on. In the sense that Islamic thought and studies are always open, changing (qabil li altaghyir), and always ready to be criticized and developed.

Furthermore, this means that Islamic thought or study is greatly influenced by the level of progress of human civilization itself. Jasser Auda, for example, provides a fairly clear picture of the three variants of the epistemological thought patterns of Islamic studies with their various characteristics; Islamic traditionalism, Islamic modernism, and post-modernism. ${ }^{17}$ The main characteristic of Islamic traditionalism lies in the notion of teleology which has shifted to theology. If teleology requires that everything be judged from its purpose, then in the view of Islamic traditionalism this goal must be judged theologically. In the context of Islamic studies, the good and bad of everything must be judged from theological

15 Turâts which literally means inheritance or legacy (heritage, patrimoine, legacy). In the realm of contemporary thought, turâts are the wealth of cultural traditions and intellectual treasures that passed down by predecessors. Turâts is a legacy of past traditions both far and near past that are present in our midst and accompany our present. The nomenclature of turâts is a product of contemporary Arabic discourse, and there is no equivalent or proper equivalent in classical Arabic literature to represent the term. See: M. Abed al-Jabiri, al-Turats wa al-Hadatsah (Beirut: Markaz Dirasat al-Wihdah al-Arabiyah, 1991), p. 23.

${ }^{16}$ One of Abid al-Jabiri's major projects is the criticism of the Arab knowledge system (naqd aql al-Araby). This effort was carried out as a process of tracing and investigating the basic foundations, methods and influence of the historical roots of Arabic culture in the tradition of reasoning. From this, it can be seen that Abid al-Jabiri pays close attention to the epistemological model that is built from Arab culture which in turn also forms Arab culture. Although the focus of the study al-Jabri is reason, Arab and not Islamic reasoning, however, as the relationship between the two cultures, then talk about Islam in the study of Arab criticism of reason is a keniscayaan.lihat Mohammad Musleh, Philosophy of Science (Yogyakarta: Thicket, 2004), p. 180.

17 Jasser Auda, Maqasid al-Shari'ah as Philosopy of Islamic Law: A Systems Approach (London: The International Institute of Islamic Thought, 2008), p. 17. 
purposes (Allah). Thus, the text becomes central in this study. ${ }^{18}$

The textual epistemology used by Islamic Traditionalism is further criticized by Islamic Modernism. To Islamic modernists, theology was seen as an idea that hindered the progress of science.

Abu Rabi 'then questioned the condition of Islamic studies today. Although several independent Muslim countries, such as Egypt, Indonesia, and Pakistan, modernization in the field of Islamic studies can be said to be inadequate - not to mention inadequate at all.

The symptoms of underdevelopment appear from various aspects; first, military elites and politicians actively provide support to traditional educational institutions only to maintain the status quo. There is a kind of mutualism symbiosis between education and power.

Second, the centrality and sensitivity of Islam. The state clearly intervened in the modern construction of Islamic studies to ensure the neutrality of religion in social and political problems. So that Islamic studies is limited to Arabic rhetoric and grammar.

Third -and this is the main symptom -, a social science and philosophical perspective does not exist. ${ }^{19}$ Abu Rabi 'own personal experience shows how social sciences do not have a place among Muslims. In fact, these social sciences are considered heretical so that it is rare to find students - especially from the Gulf - who continue their studies in the field of social science. Abu Rabi 'states:

The absence of social science philosophy or critical perspectives from the fields of Shari'ah studies can be illustrated by the fact that most students who acquire a government scholarship to pursue Reviews their graduate education abroad, especially from the Gulf states, study only the hard sciences or business administration, supposedly value-free or cricismfree subjects. In my many years in the United States (almost twenty years now), I have never encountered a single student from the Gulf pursuing a graduate degree in political science, philosophy, or history. Closing the door to any type of critical perspective has been the underpinning of the field of Religious Studies (especially Islamic Studies) and made it quite irrelevant. This fact has made it quite difficult in many Arab countries to encourage the growth of a scientific tradition, developed mainly in the West, to study the complex interplay between religion and society in the modern Arab world. The discipline of the sociology of religion is looked upon as bid'ah, or innovation, that does not convey the real essence of Islam. Just like the study of the modern Arab

18 Adonis provides several criteria for the centrality of the text in this study; (1) authority, (2) truth does not exist in the world, humans, or nature, but exists in the text, (3) an understanding of reality must be in line with the text, (4) anti-critical, meaning that it emphasizes missionary-practical moralist dogmatic thinking, (5) resurrection is a return to the basic text, the truth is in power as the guardian of the text and that truth is one so that there is no plurality and difference. Adonis, al-Tsabit wa al-Mutahawwil: Bahts fi al-Ibda wa al-Itba " inda al-Arab, trans Khairon Nahdiyyin, Volume I (Yogyakarta: LKiS, 2007), p. XXXV.

${ }^{19}$ Hassan Hanafi gave special attention to the absence of themes related to social (social) and humanity in traditional Islamic studies. In the end of his work Dirasat Islamiyyah, Hanafi specifically discusses this issue. For Hanafi, turas or classical Islamic studies too neglect the subject of the reviewer in this case human beings. Humans seem to be lost and are considered undifferentiated by text. Read: Hasan Hanafi, Dirasat Islamiyyah (Cairo: Maktabah Anglo, nd), p. 393. 
state system, the sociology of religion is a necessity in the Arab world. ${ }^{20}$

Fourth, Islamic studies only revolve around shari'ah and fiqh studies that are empty of political criticism, and empty of the relevance of the current situation. Fifth, there is a very clear distinction between theology and politics or theology and society. Theology is understood as a rite, a symbol and only as historical texts.

This has led to tension between thinking and reality, between Islam and reality. For Abu Rabi 'this fifth condition created a backward Muslim intellectual class in society. They really understand Islamic texts but do not understand how to critically examine texts in relation to the social and political conditions around them.

\section{F. Multidisciplinary in Islamic Studies; An Offer of the Way Out}

First, Abu Rabi 'realized that the study of Islam cannot be done in one aspect only. According to Abu Rabi 'there are at least four aspects in Islam: (1) Philosophical or ideological aspects. On this plain Islam has become a problem of philosophy and ideology in Arab-Islamic thought. (2) Theological aspects. At this level Islam has an open meaning. Islam can be seen from inclusive theology, namely the oneness of God. (3) Aspects of text (nash). Text is the main essence of Islamic culture, it does not emerge from a vacuum, but always has a dialectic with the historical reality of human culture. Thus it must be understood dialectically between text and reality and between text and human interpretation. Muslim history and thought is a complex blend of human (humane) and divine (naturedivine). (4) Aspects of anthropological reality. Apart from having a normative side, in Islam there has been an evolution in its historical development. Islam has stimulated the birth of complex cultural, social and political dynamics. ${ }^{21}$

Given that Islam cannot be separated from these aspects (even more or more or added), then Islamic thought or even studies must touch on these various aspects. Islamic studies cannot be carried out with only one aspect, such as text. The interrelationship between these aspects then opens wide opportunities for the use of social sciences, philosophy, politics, and other sciences in understanding Islam. The scientific monodisciplinary in Islamic studies should be abandoned as soon as possible. The development of science today has greatly contributed to the richness of perspectives in Islamic studies. Thus, inter-disciplinary or multidisciplinary is a concrete offer in unraveling the tangled threads of study Islam today. Interconnectivity aspects and disclosure aspects of the social sciences and humanities can be described as follows:

20 Ibrahim M. Abu Rabi ', "A Post September 11, Critical Assessment of Modern Islamic History", ... p. 36 . ... p. $30-31$.

${ }^{21}$ Ibrahim M. Abu Rabi ', "A Post September 11 Critical Assessment of Modern Islamic History", 


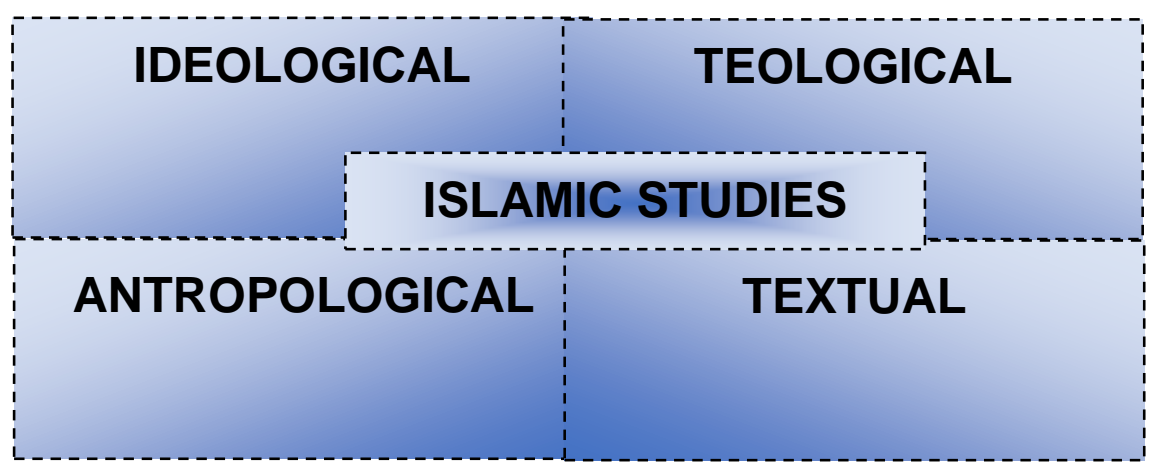

From the picture above looks cavity in Islamic studies to interact with other sciences. Quoting Amin Abdullah's theory that there is no discipline whatsoever can be closed off, no discipline is covered by fences and strict boundaries that he created himself. The boundaries of the individual disciplines are still there and visible, but they are not light or soundproof. There are small holes or pores that are embedded in the boundary walls of scientific disciplines that can be penetrated by other disciplines. ${ }^{22}$

The concept above is known as the Semipermeable ${ }^{23}$ in the description of the relationship between religion and science which is Dialogical and Integrative. The term Semipermeable comes from biological science, where the issue of Survival for the fittest is the most prominent. The relationship between science based on "causality" (Causality) and religion based on "meaning" (Meaning) is semipermeable, that isbetween the two penetrates each other. (The conflict between scientific and religious interpretations arise because the boundary between causality and meaning is semipermeable. ${ }^{24}$

Second, Abu Rabi 'wanted the birth of an intellectual who was truly involved in reviving Islamic studies and working hard to solve the problems of contemporary Muslims. In the scientific tradition,is commonly referred to as intellectual engagementintellectual engagement. The main task of this intellectual model is to do everything in its power to be independent of the interests of the authorities in maintaining the status quo. Intellectuals with the spirit of scientific objectification

22 Presented in the study orientation of new students for the Masters (S2) and Doctoral (S3) Postgraduate Programs at UIN Sunan Kalijaga Academic Year 2018/2019, September 222018. 1987), p. 1

${ }^{23}$ Holmes Rolston, Science and Religion: A Critical Survey (New York: Random House Inc,

24 Presented in the study orientation of new students for the Masters (S2) and Doctoral (S3) Postgraduate Programs at UIN Sunan Kalijaga Academic Year 2018/2019, September 222018. 
and strive to be problem solving in today's Muslim life challenges.

\section{G. Conclusion}

The Muslim world faces complex challenges in social, political, economic, and cultural aspects, which have led to mixed responses from modernist, nationalist and revivalistic Islamist groups.

The interconective integrative viewpoint sees that the integration of religion, science and culture opens up rigid, rigid, and static spaces to develop towards progressive ijtihad. The classical educational tradition that separated religion from the natural, social and humanistic sciences caused Islam to be in a lagging state. The Taliban, Al-Qaeda, and ISIS movements are the results of classical education. It takes a renewal of Islamic thought through an integrated interconnection approach so that Islam can be interpreted more comprehensively.

The Integrative Dialogical Approach with multi-disciplinary disciplines in Islamic studies is an offer given by Ibrahim Abu Rabi 'to avoid a rigid and exclusive understanding of Islamic teachings. 


\section{BIBLIOGRAPHY}

Abu Khalil, As'ad, "Revival and Renewal" dalam The Oxford Encyclopedia of the Modern Islamic World, vol. 3, ed. John L. Esposito dkk. New York : Oxford University Press, 1995.

Abu Rabi', Ibrahim M., "A Post September 11 Critical Assesment of Modern Islamic History" dalam Ian Markham dan Ibrahim M. Abu Rabi', Oxford: Oneworld Publications, 2002.

Intellectual Origins of IslamicResurgence in The Modern Arab World, New York: State University Of New York Press, 1996.

Adonis, al-Tsabit wa al-Mutahawwil: Bahts fi al-Ibda wa al-Itba' 'inda al-Arab, terj Khairon Nahdiyyin, Jilid I, Yogyakarta: LKiS, 2007.

al-Jabiri, M. Abed, al-Turats wa al-Hadatsah, Beirut: Markaz Dirasat al-Wihdah alArabiyah, 1991.

Auda, Jasser, Maqasid al-Shari'ah as Philosopy of Islamic Law: A Systems Approach, London: The International Institute of Islamic Thought, 2008.

ES. Supriyadi, Ngruki dan Jaringan Terorisme, Melacak Jejak Abu Bakar Ba'asyir dan Jarigannya dari Ngruki sampai Bom Bali, Jakarta: Al Mawardi Prima, 2003.

Esposito, John L. (ed), The Oxford Encyclopedia of The Modern Islamic Word, vol. 4, New York: Oxford University Press, 1995.

Hanafi, Hasan, Dirasat Islamiyyah, Kairo: Maktabah Anglo, tt.

Hinnebusch, Raymond, The American Invasion of Iraq: Causes and Consequences, Perceptions, $2007 \quad$ (http:/sam.gov.tr/wp-content/upload/2012/01/RaymondHinnebusch.pdf)

Kuswaya, Adang, Melawan Islamophobia, Sukoharjo: Kekata Group, 2020.

Mahfudh, Hasan, Dari Ibrahim M. Abu Rabi' tentang Problematika Studi IslamKontemporer, Millati, Journal of Islamic Studies and Humanities Vol.1, No.1, Juni 2016.

Munthe, Abdul Karim, dkk, Meluruskan Pemahaman Hadis Kaum Jihadis, Jakarta: Yayasan Pengkajian Hadis el-Bukhari, 2017.

Muslih, Mohammad, Filsafat Ilmu, Yogyakarta: Belukar, 2004.

Rolston, Holmes, Science and Religion: A Critical Survey, New York: Random House Inc, 1987)

Susilo, Taufik Adi. Ensiklopedia Pengetahuan Dunia Abad 20. Javalitera. Yogyakarta 2010. 